\title{
Interaction between two luteal cell types from the corpus luteum of the sow in progesterone synthesis in vitro
}

\author{
Meredith Lemon* and P. Mauléon \\ I.N.R.A., Station de Physiologie de la Reproduction, 37380 Nouzilly, France
}

\begin{abstract}
Summary. Populations of two types of luteal cell (large and small) were prepared from CL of sows at 60 days of gestation. When the two cell types were recombined and incubated for $2 \mathrm{~h}$, the amount of progesterone released into the medium was almost twice the sum of that released by each cell type alone. When the cells were superfused in vitro, in an 'in series' arrangement such that the superfusate from one cell type then passed through the chamber containing the second cell type, the small cells were responsible for increasing the production of progesterone by the large cells. When cell populations were superfused with media containing inhibitors of progesterone synthesis, trilostane completely blocked progesterone release but aminoglutethimide only reduced progesterone output by half, even when the concentration of inhibitor was increased. Addition of pregnenolone to the superfusion medium increased progesterone production by both cell types approximately 3 -fold, whereas addition of cholesterol only increased progesterone production by the large cells.
\end{abstract}

\section{Introduction}

The early observations of Corner (1919) on the presence of two types of luteal cell in the corpus luteum (CL) of the sow are well known, and have been verified by electron microscopy for CL from pregnant and cyclic sows (Cavazos et al., 1969; Belt, Cavazos, Anderson \& Kraeling, 1970). Lemon \& Loir (1977) isolated these two morphologically distinct cell types from pregnant sow CL and measured their individual steroid production during superfusion in vitro. The large luteal cells, which probably originate from the granulosa after ovulation, contribute the major part of progesterone, although the smaller cells, probably of thecal origin, also secrete small quantities of progesterone in the absence of gonadotrophic stimulation. Luteinizing hormone (LH) greatly increases progesterone output by the smaller cells.

Because of the interest in the associations between cell types, and in particular those between follicular granulosa and theca cells (Lacroix, Eechaute \& Leusen, 1974; Makris \& Ryan, 1975; Fortune \& Armstrong, 1977; Fowler, Fox, Edwards \& Steptoe, 1978), the present experiments were designed to show whether a similar association between luteal cell types might be maintained in the sow CL, and if so, to suggest a possible mechanism by which the cells may interact.

\section{Chemicals}

\section{Materials and Methods}

The chemicals used were the same as those described by Lemon \& Loir (1977), with the following additions; aminoglutethimide (elipten phosphate) was generously donated by

* Present address: Domaine de Saint Maurice, 40270 Grenade sur l'Adour, France. 
Ciba-Geigy, Basle, Switzerland, and trilostane by Stirling-Winthrop Research Institute, Rensselaer, New York. Pregnenolone was obtained in crystalline form from Steraloids, and cholesterol from Merck, Darmstadt, Germany.

\section{Preparation of cell populations}

Large White cross-bred sows at 60 days of pregnancy were used for all experiments. The animals were slaughtered, and immediately the ovaries were removed and the CL excised. Luteal tissue was dissociated enzymically, with some minor modifications being made to the method described by Lemon \& Loir (1977). The luteal tissue was cut into small pieces with razor blades, and 2-g tissue pieces were weighed and used for each dissociation ( $2 \mathrm{~g}$ tissue represents 4-5 CL). After preliminary washing for $10 \mathrm{~min}$ in $10 \mathrm{ml}$ Krebs-Ringer-bicarbonate buffer, $\mathrm{pH} 7.4$ (Umbreit, Burris \& Stauffer, 1964), containing $0.2 \%$ glucose and $4 \%$ BSA, the tissue was incubated for $30 \mathrm{~min}$ in $10 \mathrm{ml}$ of the same buffer containing, in addition, $0.3 \%$ collagenase and $0.2 \%$ hyaluronidase. The cells liberated during this incubation were discarded. The remaining pieces were washed three times in $10 \mathrm{ml}$ Dulbecco's modified Eagle medium (DMEM: GIBCO, New York), then incubated with $10 \mathrm{ml}$ DMEM containing $0.3 \%$ trypsin and $0.005 \%$ DNase. After each $15 \mathrm{~min}$ incubation, the freed cells were decanted from the remaining tissue pieces, centrifuged for $4 \mathrm{~min}$ at $300 \mathrm{~g}$ and the supernatant removed. The pellet was re-suspended in 10 $\mathrm{ml}$ DMEM containing $0.5 \% \mathrm{BSA}, 3 \mathrm{mM}-\mathrm{CaCl}_{2}, 0 \cdot 25 \%$ Lima bean trypsin inhibitor and 5000 units penicillin; this was the washing medium of Wu, Wiest \& Enders (1976). The cells liberated after 4 incubations with trypsin and DNase were pooled, washed twice with the same washing

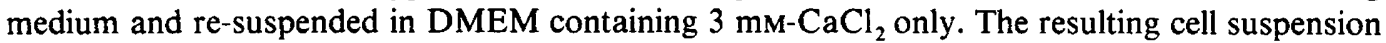
contained a mixture of large luteal cells of 30-50 $\mu \mathrm{m}$ diameter, smaller, highly refringent cells of similar appearance under phase contrast, and $15-20 \mu \mathrm{m}$ in diameter, epithelial cells, blood cells and cellular debris. Haemocytometer counts were made of the numbers of large and small luteal cells in the final suspension, before separation. The numbers of cells varied from one preparation to another-for a total of 20 such dissociations, the mean numbers were $2.68 \pm 1.38 \times 10^{6}$ large luteal cells and $2.79 \pm 1.63 \times 10^{6}$ small luteal cells.

The cells were then separated according to size by sedimentation at unit gravity as described previously (Lemon \& Loir, 1977). The total number of cells contained in the suspension was close to the maximum that could be separated efficiently in the sedimentation system used. The two populations of luteal cells thus obtained were used immediately for incubation or superfusion in vitro.

\section{Incubation}

Each luteal cell population was suspended in DMEM containing 1\% BSA and antibiotics (10 $\mathrm{mg}$ streptomycin $/ \mathrm{ml}$ and $5 \times 10^{3}$ units penicillin $/ \mathrm{ml}$ ) at $\mathrm{pH} 7.4$. Aliquots of $1 \mathrm{ml}$ cell suspension were placed in $10 \mathrm{ml}$ Erlenmeyr flasks, either each cell population separately, or the two re-combined, and the volume was adjusted to $4 \mathrm{ml}$ with the same medium. The flasks were flushed with oxygen:carbon dioxide $(95: 5, \mathrm{v} / \mathrm{v})$ at 0 and $60 \mathrm{~min}$, stoppered and incubated at $37^{\circ} \mathrm{C}$ for $2 \mathrm{~h}$ in a shaking water bath. The contents of each flask were then centrifuged for $4 \mathrm{~min}$ at $300 \mathrm{~g}$. The supernatant was decanted and frozen at $-20^{\circ} \mathrm{C}$ for progesterone assay.

\section{Superfusion}

The superfusion system was the same as that described by Lemon \& Loir (1977). The chambers containing the appropriate cell fractions, mixed with a suspension of Biogel-P6, were immersed in a water bath at $37^{\circ} \mathrm{C}$, while the reservoir containing the superfusion medium (DMEM containing $10 \%$ serum from an ovariectomized hysterectomized sow) was kept in an ice 
bath. Medium was passed through the system at a constant rate of $10 \mathrm{ml} / \mathrm{h}$ using an ISCO 2channel peristaltic pump, and $5 \mathrm{ml}$ fractions were collected every $30 \mathrm{~min}$. In some experiments, the cells were superfused in an 'in series' arrangement. The medium passed first through one chamber and then through the second chamber, each chamber containing a separated cell population, and $5 \mathrm{ml}$ fractions of the final superfusate were collected every $30 \mathrm{~min}$. In an experiment of this type, half of each cell population was superfused alone (controls) and the other half in the 'in series' system. For a total of 10 superfusion experiments taken at random, the mean numbers of cells used were $1.22 \pm 0.63 \times 10^{5}$ luteal cells and $2.00 \pm 1 \cdot 10 \times 10^{5}$ small luteal cells.

\section{Progesterone assays}

Each 30 min sample of superfusion medium was assayed for progesterone: $1 \mathrm{ml}$ medium was extracted with 10 volumes $n$-hexane. The extracts were evaporated to dryness and assayed by the competitive protein-binding technique of Bassett \& Hinks (1969) as described for progesterone by Thorburn, Bassett \& Smith (1969). This method uses a 1 in 50 dilution of dog plasma previously passed through a large column of Sephadex-G25 at $45^{\circ} \mathrm{C}$, and separation of bound and free steroid is carried out on small columns of $0.5 \mathrm{~g}$ Sephadex-G25 at $4^{\circ} \mathrm{C}$. The method reliably measures between 0.25 and $16.0 \mathrm{ng}$ progesterone, and was used here, rather than radioimmunoassay, because of the high concentrations of progesterone in the samples to be assayed. Thus, high sensitivity was not an important pre-requisite. Assay blank values of $0 \cdot 14 \pm$ $0.10 \mathrm{ng}(n=12)$ were obtained after extraction and assay of $1 \mathrm{ml}$ samples of superfusion medium. The efficiency of extraction with $n$-hexane was $85 \%$, and no correction was made for procedural losses. The assay is specific for progesterone under the conditions described in this study, and values were estimated with a precision of $8 \%$.

To dilute samples containing large amounts of progesterone, the dried hexane extract was re-dissolved in $1 \mathrm{ml}$ methanol and an appropriate aliquot removed, dried and assayed.

For the superfusion studies, the results of the progesterone assays were expressed as ng progesterone $/ 30 \mathrm{~min}$ or $\mathrm{ng}$ progesterone $/ \mathrm{h} / 10^{5}$ cells, since $10^{5}$ was the nearest to the number of cells of each type actually used in the experiments. Each text-figure presents the results of a single experiment. Multiple experiments have not been pooled due to the variability in progesterone production among different cell preparations. Because of this variability, controls were included in each experiment so that comparison of progesterone production under various experimental conditions could be carried out with the same cell preparation for a given experiment.

\section{Results}

\section{Interaction between large and small cells}

When large and small luteal cells were recombined and incubated together in the same flask (Text-fig. 1), the amount of progesterone released into the incubation medium during a $2 \mathrm{~h}$ period was almost twice the amount represented by the sum of each cell type incubated separately (175\% and $195 \%$ in two experiments). The difference in absolute values of progesterone in the two experiments is due to there being almost twice the number of cells in the first experiment as in the second. Progesterone production by the cell mixture has not been expressed relative to a constant number of cells, because the enhanced progesterone production may vary according to the ratio of small to large cells.

The 'in series' superfusion experiments were designed to determine which cells have the stimulating effect and which are stimulated. When the superfusate from the chamber containing the small cells was passed through that containing the large cells, the total amount of progesterone released into the medium exceeded by $22 \%$ that represented by the sum of the production by each cell type alone (Text-fig. $2 a$ ). When the superfusate from the large cells was 

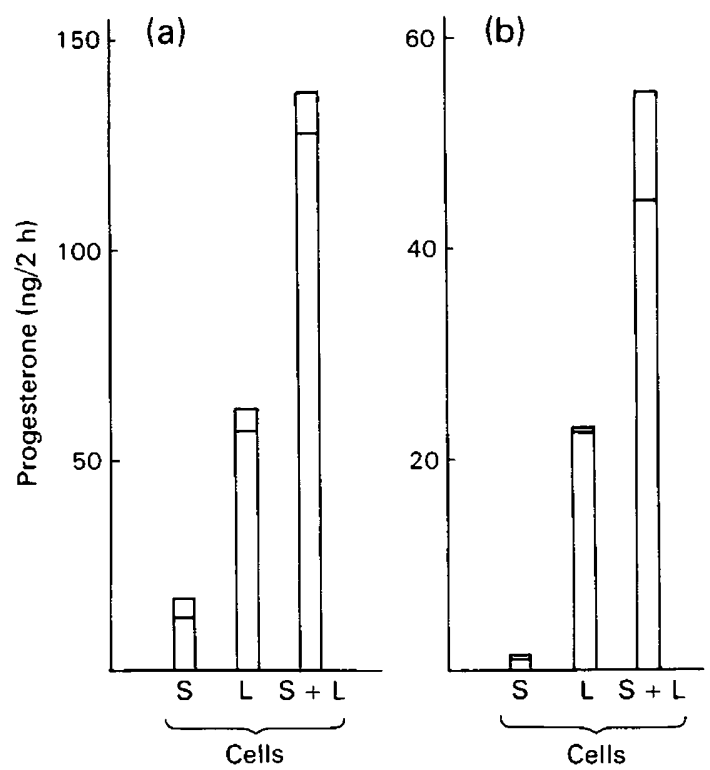

Text-fig. 1. Progesterone accumulated during a 2-h in-vitro incubation of large (L) and small (S) luteal cells, and of a mixture of the two cell types from pig CL. Horizontal bars represent the results of duplicate assays of the same incubation medium. Each incubation flask contained (a) $5.3 \times 10^{4}$ small cells and/or $9 \times 10^{4}$ large luteal cells, and (b) $2.5 \times 10^{4}$ small cells and/or $2.5 \times$ $10^{4}$ large luteal cells.

passed through the chamber containing the small cells, there was no such increment in progesterone production (Text-fig. 2b). In a second such experiment, a similar result was obtained in that, during the first $10 \mathrm{~h}$ of superfusion, when the superfusion medium passed through the chamber containing the small cells and then through that containing the large cells, progesterone accumulation was $26 \%$ greater than the sum of progesterone release by small and large cells separately. Again, in the reverse direction, no such increase was seen. Differences were calculated over the first $10 \mathrm{~h}$ of superfusion because all experiments in this study show that, after 10-12 h, progesterone production begins to decrease and the cells cannot be considered to be metabolizing normally thereafter.

Since the concentration of progesterone in each sample of superfusate is measured with a precision of $8 \%$, the results of the above experiments cannot be due to variation in the assay.

The stimulatory effect of the small cells on the amount of progesterone produced by the large cells can occur in the absence of gonadotrophic stimulation.

The increment in progesterone production was never as great as that obtained during the incubation experiments; perhaps because the medium passed too quickly through the system to obtain a maximal effect.

\section{Effect of inhibitors of progesterone synthesis}

Trilostane, a synthetic analogue of ethinyl testosterone, which is reported to inhibit $\Delta^{5}, 3 \beta$-hydroxysteroid dehydrogenase adrenal activity in vitro (Potts, Creange, Harding \& Schane, 1978), was added to the superfusion medium at a concentration of $2 \times 10^{-5} \mathrm{M}$. As shown in Text-fig. 3, when the cells, both large and small, came into contact with this compound, the production of progesterone was immediately reduced to almost zero. Thus, when the conversion of pregnenolone to progesterone was prevented, progesterone release was abolished: This experiment also serves to demonstrate that the superfusion system described here and in 


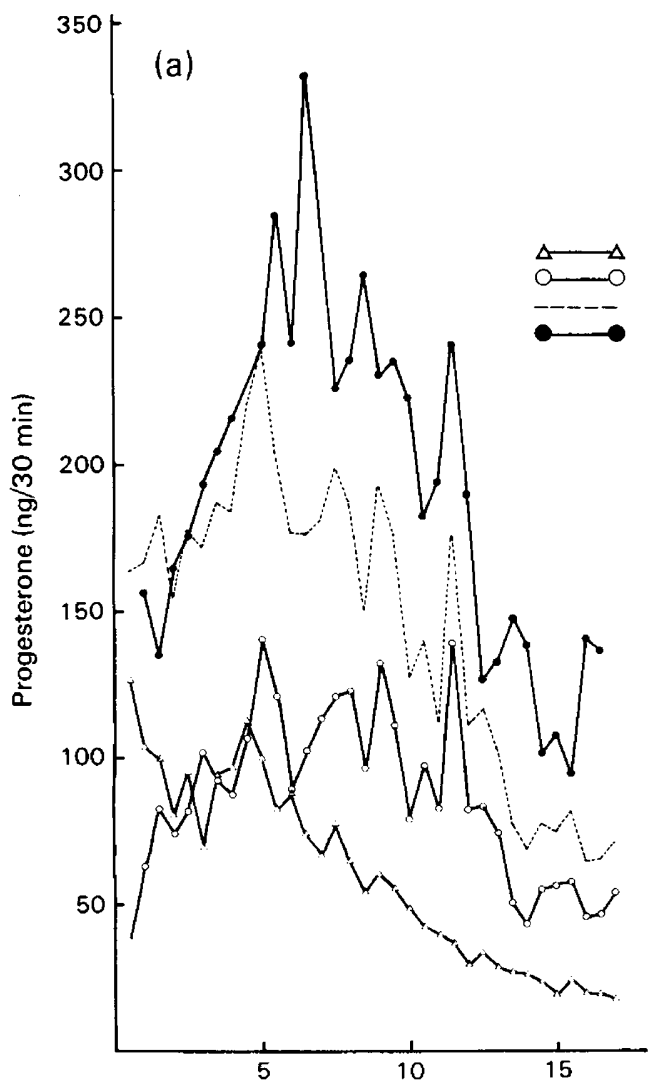

small cells superfused alone large cells superfused alone sum of progesterone released by each cell type alone progesterone release after 'in series' superfusion

(a) small cells $\rightarrow$ large cells

(b) large cells $\rightarrow$ small cells

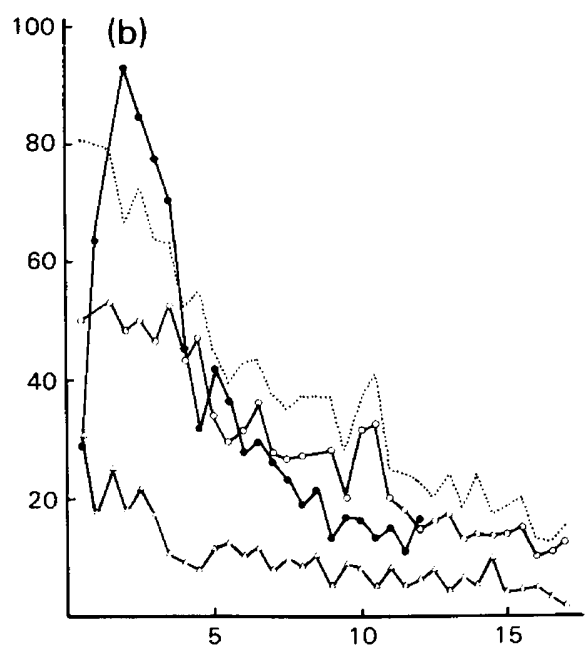

Hours

Text-fig. 2. Progesterone released during superfusion of porcine luteal cells in vitro, with each cell type separately and 'in series' so that the perfusate passed over (a) the small cells and then the large cells and (b) the large cells and then the small cells. The numbers of large and small cells superfused 'in series' was the same as the number of each cell type superfused separately: (a) 2.6 $\times 10^{5}$ large cells and $7.2 \times 10^{5}$ small cells; (b) $5.5 \times 10^{5}$ large cells and $4.5 \times 10^{5}$ small cells.

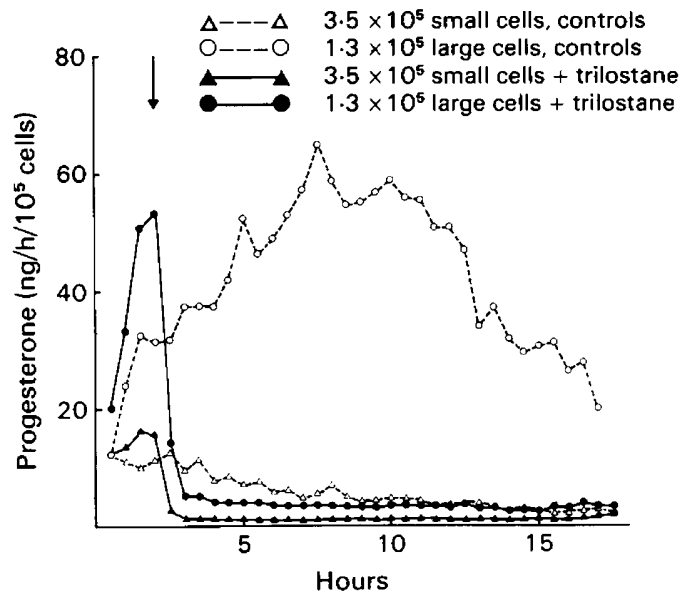

Text-fig. 3. Progesterone released by two types of porcine luteal cell during superfusion with and without addition of trilostane (arrow) $\left(2 \times 10^{-5} \mathrm{M}\right)$ to the superfusion medium. 
Lemon \& Loir (1977) actually measures progesterone production and not release of pre-formed progesterone.

Aminoglutethimide (elipten phosphate) was also added to the medium during superfusion of both large and small luteal cells. This compound inhibits the cholesterol side-chain cleavage (desmolase) enzyme system (Salomon \& Sherman, 1976), thus inhibiting conversion of cholesterol to pregnenolone. The results (Text-fig. 4) show that even with the higher concentration of aminoglutethimide $\left(2 \times 10^{-5} \mathrm{M}\right)$, progesterone production by the large cells was not diminished by more than $50 \%$ over the 18 -h period of superfusion.

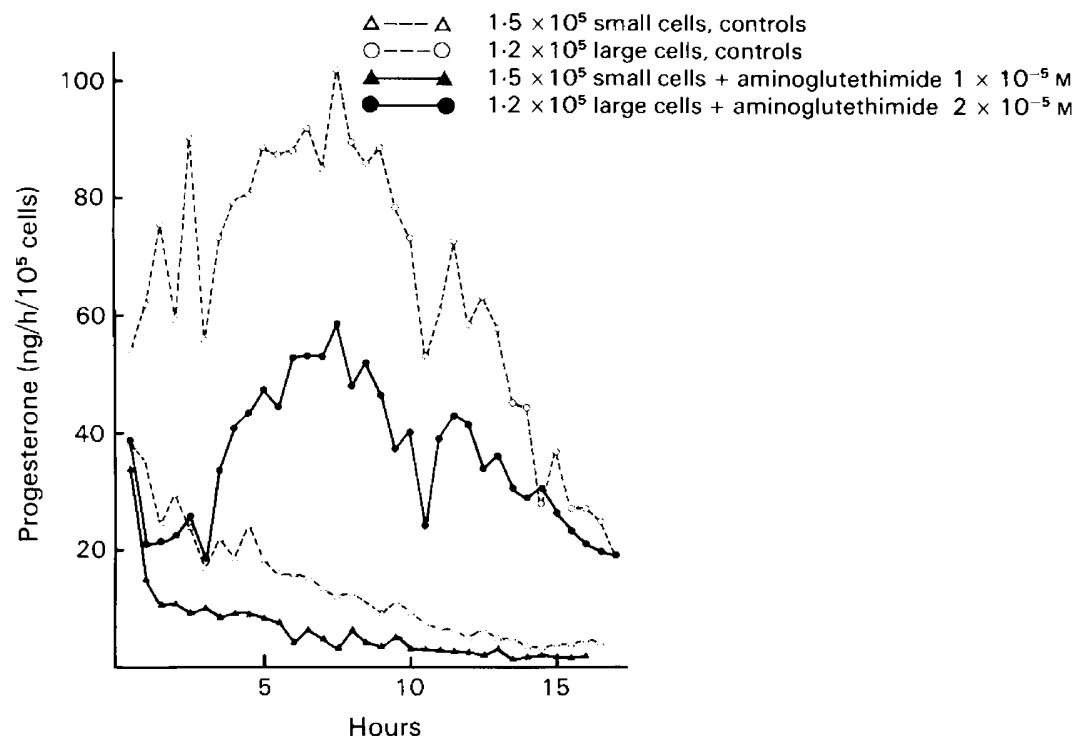

Text-fig. 4. Progesterone released by two types of porcine luteal cell during superfusion, with and without addition of aminoglutethimide to the superfusion medium.

\section{Effect of precursors of progesterone synthesis}

Populations of large and small cells were superfused with medium alone (controls) or with medium containing cholesterol at a concentration of $50 \mu \mathrm{g} / \mathrm{ml}$. All preparations received two pulses, $10 \mu \mathrm{g}$ each, of porcine LH $3 \mathrm{~h}$ apart. The small cells produced the same amounts of progesterone, and responded in the same way to $\mathrm{LH}$, whether the medium contained cholesterol or not (Text-fig. 5b), but the large cells produced increasing quantities of progesterone when superfused with medium containing cholesterol even before LH was administered (Text-fig. 5a). In three other experiments during part of which the large cells were superfused with medium containing cholesterol, progesterone production was increased by approximately $20 \%$ relative to controls superfused with medium alone. In all cases, the increase was short-lived (3-4 h), and progesterone production was then similar to that of the controls.

Progesterone production by the large cells superfused with medium containing cholesterol continued to increase after LH was administered. The difference in progesterone production between the experimental and control cells was $20 \%$ before the first LH pulse, $46 \%$ between the first and second LH pulse, and $87 \%$ thereafter. These differences appear to be due to the combination of cholesterol and LH.

When pregnenolone was added to the superfusion medium at a concentration of $4 \mu \mathrm{g} / \mathrm{ml}$, the progesterone production by both types of luteal cell was increased approximately 3-fold (Text-fig. 6). 


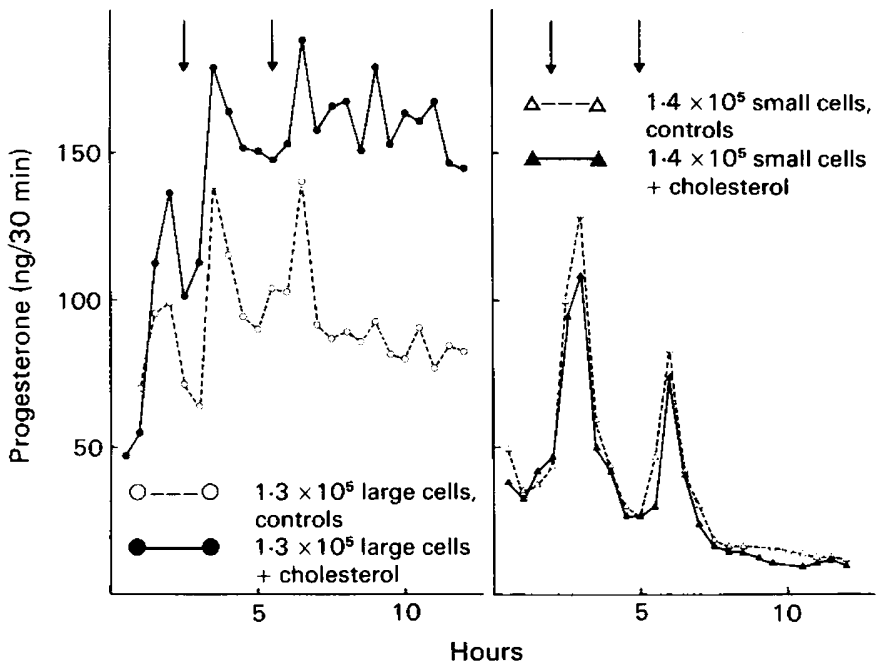

Text-fig. 5. Progesterone released by two types of porcine luteal cell during superfusion, with and without addition of cholesterol $(20 \mu \mathrm{g} / \mathrm{ml})$ to the superfusion medium. Two pulses, each of $10 \mu \mathrm{g}$, of porcine LH were administered (arrows) to all cells.

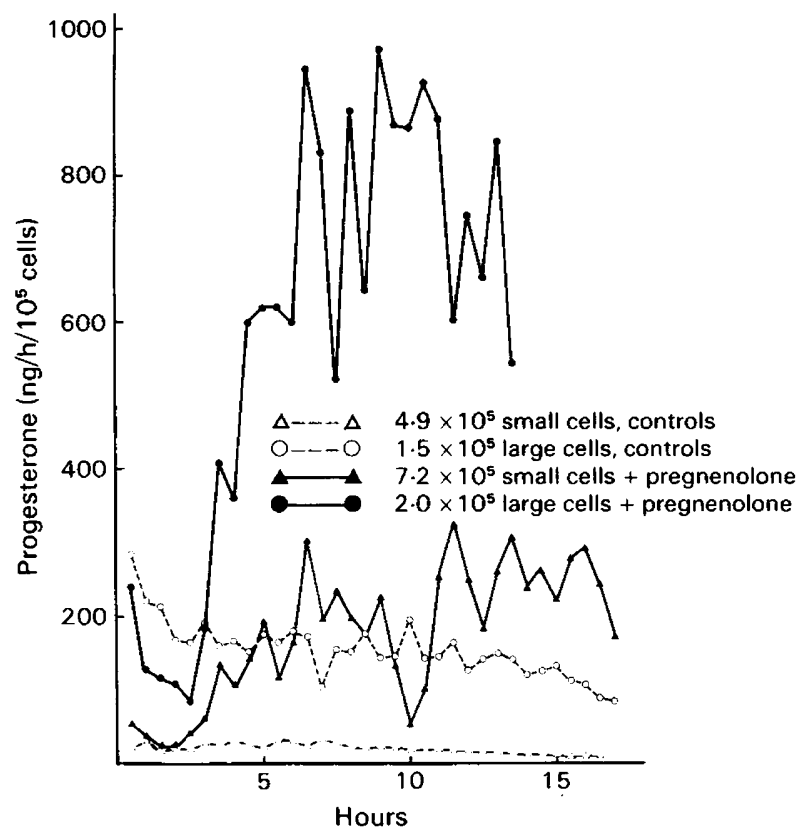

Text-fig. 6. Progesterone released by two types of porcine luteal cell during superfusion, with and without addition of pregnenolone $(4 \mu \mathrm{g} / \mathrm{ml})$ to the superfusion medium.

\section{Discussion}

Both small and large cells of the pig CL have an active $3 \beta$-hydroxysteroid dehydrogenase system, and the capacity to synthesize and secrete progesterone. This was demonstrated when pregnenolone was added to the superfusion medium: there was a striking increase in progesterone production by both luteal cell types, showing that they can convert pregnenolone to 
progesterone. Addition of trilostane inhibitor showed that neither cell type stores progesterone, since progesterone production was reduced almost immediately to basal levels.

The fact that only $50 \%$ inhibition of progesterone production was obtained with aminoglutethimide inhibitor could suggest that these cells contain sufficient reserves of pregnenolone to continue to produce progesterone, over the period studied, in the absence of other precursor. However, it is more likely that inhibition of the cholesterol desmolase enzyme complex was incomplete at the concentrations of inhibitor used. Given the activity of the $3 \beta$-hydroxysteroid dehydrogenase system, any pregnenolone produced by either cell type would be metabolized immediately rather than stored.

The large cells responded to exogenous cholesterol but the small cells did not (Text-fig. 5). From this, it might be argued that cholesterol is stored by the small cells for conversion to progesterone. This idea is consistent with the abundance of lipid material in the small cells (Lemon \& Loir, 1977). We have also shown (Lemon \& Loir, 1977) that the small luteal cells respond to a pulse of $\mathrm{LH}$ by an immediate, large though short-lived peak of progesterone, and that the response by the large cells is later and more attenuated. These results suggest that the small cells also contain abundant LH receptors in the cell membrane. Armstrong \& Dorrington (1977) concluded that the role of LH is to mobilize stores of cholesterol, and the difference in the response to $\mathrm{LH}$ by the two cell types of the pig $\mathrm{CL}$ may be a reflection of the availability of cholesterol. It may be that the small cells, which respond rapidly to LH, contain substantial stores of cholesterol that are rapidly mobilized by LH, while the large cells, which contain less lipid material, do not react in the same way. Progesterone synthesis may therefore be dependent on both LH receptors and reserves of progesterone precursors, which are different for each type of luteal cell. The small cells in the corpus luteum of the sow in vivo may constitute a reserve of cholesterol which is mobilized under the influence of $\mathrm{LH}$.

The incubation experiments presented in this study show that there is indeed an interaction between the two cell types in the synthesis of progesterone. Furthermore, superfusion studies carried out 'in series' show that it is the small cells which are responsible for the enhancement of progesterone synthesis by the large luteal cells.

O'Shea, Cran \& Hay (1979) noted the presence of small and large luteal cells in the ovine CL. The ultrastructure of each cell type differed markedly, but indicated that both were involved in steroid secretory functions. O'Shea et al. (1979) remarked on the disposition of the small and large cells within the corpus luteum, the small cells often being interposed between large cells and capillaries, and forming complex surface relationships with large luteal cells. They concluded that these features of the small cells suggested a direct interaction with large cells. Histological sections of sow corpora lutea show a similar disposition of large and small cells (Lemon \& Loir, 1977). If the small cells are of thecal origin, while the large cells are derived from the granulosa, the interaction shown here would be a continuation of the interaction between cells of the theca and those of the granulosa in the synthesis of steroids by the ovarian follicle.

The micro-transplant experiments of Falck (1959) in the rat, were the first to suggest that co-operation exists between these two ovarian cell types which is necessary for oestrogen secretion to occur. Subsequent in-vitro experiments led to the hypothesis that the theca interna cells produce the androgen substrate which is transported to the granulosa cells for aromatization to oestrogens. This was shown to be likely for oestrogen synthesis in the rat (Fortune \& Armstrong, 1977), hamster (Makris \& Ryan, 1975), cow (Lacroix et al., 1974) and woman (Fowler et al., 1978). Baird (1977) presented in-vivo evidence for this theory in the sheep. The subject has given rise to much controversy, but it now seems likely that the granulosa cells synthesize part of the androgen precursor for conversion to oestradiol-17 $\beta$ and that part arises from thecal androgen (Henderson, 1979).

Makris \& Ryan (1977) have produced evidence in favour of an interaction between the theca and granulosa cells of the hamster for progesterone synthesis after the preovulatory gonadotrophin surge. Incubations of isolated granulosa or theca from preovulatory follicles or 
the two recombined, in the presence of $\mathrm{LH}$ and $\mathrm{FSH}$, indicated an interaction between these two cell types for maximal progesterone synthesis.

We have now shown that there is a similar interaction between small and large cells of the pig CL for progesterone synthesis, with cholesterol being available in the small cells for mobilization to give maximal progesterone production by the large cells.

However, it is possible that the small cells produce another factor, such as testosterone or dihydrotestosterone, which stimulates progesterone production by the large cells. The production of progesterone by granulosa cells cultured in vitro is influenced by androgens (Schomberg, Stouffer \& Tyrey, 1976; Makris \& Ryan, 1977), and it has been postulated that corpus luteum formation and ultimate function may be influenced by a similar androgen-dependent mechanism (Schomberg, Williams, Tyrey \& Ulberg, 1978).

We thank Dr M. Loir for his continued advice and encouragement, and Noelle Poulain and Maryvonne Lanneau for their valuable technical assistance.

\section{References}

Armstrong, D.T. \& Dorrington, J.H. (1977) Estrogen biosynthesis in the ovaries and testes. In Regulatory Mechanisms affecting Gonadal Hormone Action, pp. 217-258. Eds J. A. Thomas \& R. L. Singhal. University Park Press, Baltimore.

Baird, D.T. (1977) Evidence in vivo for the two-cell hypothesis of oestrogen synthesis by the sheep Graafian follicle. J. Reprod. Fert. 50, 183-185.

Bassett, J.M. \& Hinks, N.T. (1969) Micro-determination of corticosteroids in ovine peripheral plasma: effects of venipuncture, corticotrophin, insulin and glucose. J. Endocr. 44, 387-403.

Belt, W.D., Cavazos, L.F., Anderson, L.L. \& Kraeling, R.R. (1970) Fine structure and progesterone levels in the corpus luteum of the pig during pregnancy and after hysterectomy. Biol. Reprod. 2, 98-113.

Cavazos, L.F., Anderson, L.L., Belt, W.D., Henricks, D.M., Kraeling, R.R. \& Melampy, R.M. (1969) Fine structure and progesterone levels in the corpus luteum of the pig during the estrous cycle. Biol. Reprod. 1, 83-106.

Corner, G.W. (1919) On the origin of the corpus luteum of the sow from both granulosa and theca interna. Am.J. Anat. 26, 117-183.

Falck, B. (1959) Site of production of oestrogen in rat ovary as studied in micro-transplants. Acta physiol. scand. 47, Suppl. 163, 94/101.

Fortune, J.E. \& Armstrong, D.T. (1977) Androgen production by theca and granulosa isolated from proestrous rat follicles. Endocrinology 100, 13411347.

Fowler, R.E., Fox, N.L., Edwards, R.G. \& Steptoe, P.C. (1978) Steroid production from 17 $\alpha$-hydroxypregnenolone and dehydroepiandrosterone by human granulosa cells in vitro. J. Reprod. Fert. 54, 109-117.

Henderson, K.M. (1979) Gonadotrophic regulation of ovarian activity. Br. med. Bull. 35, 161-166.

Lacroix, E., Eechaute, W. \& Leusen, I. (1974) The biosynthesis of estrogens by cow follicles. Steroids 23, 337-356.
Lemon, M. \& Loir, M. (1977) Steroid release in vitro by two luteal cell types in the corpus luteum of the pregnant sow. $J$. Endocr. 72, 351-359.

Makris, A. \& Ryan, K.J. (1975) Progesterone, androstenedione, testosterone, estrone and estradiol synthesis in hamster ovarian follicle cells. Endocrinology 96, 694-701.

Makris, A. \& Ryan, K.J. (1977) Evidence for interaction between granulosa cells and theca in early progesterone synthesis. Endocr. Res. Commun. 4, 233-246.

O'Shea, J.D., Cran, D.G. \& Hay, M.F. (1979) The small luteal cell of the sheep. J. Anat. 128, 239-251.

Potts, G.O., Creange, J.E., Harding, H.R. \& Schane, H.P. (1978) Trilostane, an orally active inhibitor of steroid biosynthesis. Steroids 32, 257-267.

Salomon, D.S. \& Sherman, M.I. (1976) Gonadotrophin stimulation of progesterone synthesis by midpregnancy mouse ovarian cells in vitro. Endocrinology 99, 800-808.

Schomberg, D.W., Stouffer, R.L. \& Tyrey, L. (1976) Modulation of progestin secretion in ovarian cells by $17 \beta$-hydroxy- $5 \alpha$-androstan-3-one (dihydrostestosterone): a direct demonstration in monolayer culture. Biochem. Biophys. Res. Commun. 68, 77-81.

Schomberg, D.W., Williams, R.F., Tyrey, L. \& Ulberg, L.C. (1978) Reduction of granulosa cell progesterone secretion in vitro by intra-ovarian implants of antiandrogen. Endocrinology 102, 984-987.

Thorburn, G.D., Bassett, J.M. \& Smith, I.D. (1969) Progesterone concentration in the peripheral plasma of sheep during the oestrous cycle. $J$. Endocr. 45, $459-469$.

Umbreit, W.W., Burris, R.H. \& Stauffer, J.F. (1964) Manometric Techniques and Tissue Metabolism, 4th edn. Burgess Publ. Co., Minneapolis.

Wu, D.H., Wiest, W.G. \& Enders, A.C. (1976) Luteotropic regulation of dispersed rat luteal cells in early pregnancy. Endocrinology 98, 1378-1389.

Received 25 March 1981 